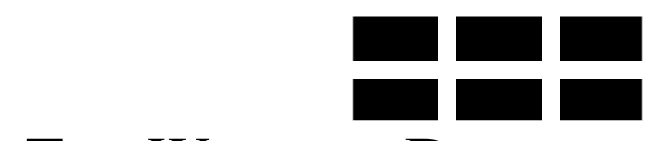

THE WILLIAM DAVIDSON INSTITUTE AT THE UNIVERSITY OF MICHIGAN BUSINESS SCHOOL

Minimum Wages, Inequality and Globalization

\author{
By: T. H. Gindling and Katherine Terrell
}

William Davidson Institute Working Paper Number 700 May 2004 


\title{
Minimum Wages, Inequality and Globalization ${ }^{*}$
}

\author{
T. H. Gindling \\ Katherine Terrell \\ University of Maryland \\ University of Michigan \\ Baltimore County \\ Gindling@umbc.edu \\ CEPR,IZA,WDI \\ Terrell@umich.edu
}

May 14, 2004

\begin{abstract}
This paper contributes to our understanding of the impact of institutions on incomes of workers in developing countries by rigorously addressing the question as to whether changes in minimum wages can change the inequality of the distribution of earnings. More specifically, we analyze whether changes in Costa Rica's complex institution of multiple minimum wages in the 1980s and 1990s acted as a countervailing force to the unequalizing effect of globalization. Using annual data on workers from the 1987-1997 household surveys, it is shown that changes in the legal minimum wages did indeed have an effect on wage inequality and that these changes would not have been captured using the simple interpretation of minimum wages found in much of the literature.
\end{abstract}

JEL Classification: J23, J31, J38

Keywords: minimum wages, employment, wages, Costa Rica

\footnotetext{
*We would like to thank Justine Wagner for her assiduous research assistance and participants in the Conference on Globalization Law and Development for useful comments. Staff members at the Central Bank and Ministry of Labor and Social Security were very helpful in providing us with data and important information on minimum wages. We are especially grateful to José Pablo Carvajal, Orlando Garcia and Yabera Alvarado of the Ministry of Labor. We would like to acknowledge generous support from the NSF (grant SES0111783).
} 


\section{Introduction}

A considerable number of studies have shown that earnings inequality of workers around the world has widened with the onset of globalization, and that rising wages of skilled workers relative to unskilled workers is an important cause of this increase in inequality. Various explanations exist for the rising relative wages of the skilled to unskilled workers in Asia, Latin America and the US during the 1980s and 1990s. Most authors believe that changes in the demand for labor favoring the skilled are more important than changes in the supply of skilled or unskilled labor, but there is still much controversy as to what is driving the changes in demand. Some claim trade liberalization is the primary source (offering mechanisms other than those proposed in the Hecksher-Ohlin and Stolper-Samuleson models) whereas others point to skillbiased technical change (Berman, Bound and Machin, 1998; Card and DiNardo, 2002; Feenstra and Hanson, 1996), which can be driven by trade (Pavnick et al., 2002 for Brazil) or by foreign direct investment (Feenstra and Hanson, 1997, for Mexico; Skuratowicz, 2000, for Poland; Wu, 2001, for China).

Costa Rica was no exception to this trend of globalization and increasing earnings inequality. Earnings inequality rose from 1992 to 1999, as the country introduced trade liberalization and other structural adjustment reforms. Gindling and Trejos (2003) show that one of the most important measurable causes of the rise in earnings inequality in Costa Rica was an increase in returns to education (skills). Robbins and Gindling (1999) show that the increase in relative wages for skilled workers in Costa Rica was most likely due to changes in the relative demand for more skilled workers and is coincident with trade liberalization. However, Gindling and Trejos (2003) also show that a significant part of the change in earnings inequality in Costa Rica cannot be explained by measurable factors such as changes in education, hours worked, sector of employment, or region of residence.

We argue in this paper that the institution of the minimum wage is also an important factor explaining changes in earnings inequality in Costa Rica and it can be an important factor in many developing countries. This study is a departure from the literature on institutions and development, which tends to analyze the impact of a more generally defined set of institutions using data on a number of countries. (The paper by Katerina Pistor in this volume is an example.) In this paper we analyze detailed changes in one institution in one country, using 
panel data over time. We argue that it is important to understand well how institutions are structured when trying to measure their impact.

How might minimum wages impact the dispersion of wages paid in a country? In countries, such as the U.S., where there is only one minimum wage that is considered to be the floor for all wages, one might expect to see dispersion rise as the floor falls. DiNardo, Fortin and Lemieux (1996) show that the erosion of the real value of in the minimum wage contributed to rising wage inequality in the US in the 1980s. However, in countries where there is more than one minimum wage, one should take into account changes in the whole structure of minimum wages when looking at the effects of minimum wages on wage inequality. Costa Rica is such a country and, as seen in Table 1, there are at least 40 other countries which have multiple minimum wages set by different dimensions (such as occupation, industry and region). For example, in Argentina there are dozens of minimum wages for agricultural workers (set by region, activity and occupation) and one wage for all other economic activities. In Mexico there are 267 minimum wages (set by three geographic areas and 88 occupations, plus one general minimum wage for each area). In Brazil there were 39 regional minimum wages from 19631984. ${ }^{1}$ Studies of these countries which use only one minimum wage when examining the impact of minimum wages on wage inequality (e.g., Cortez, 2001 and Bell, 1997) may provide biased estimates of the effect.

We proceed in Section 2 of the paper to review the findings in previous studies of wage inequality in Costa Rica. In Section 3 we describe the institution of minimum wages and our expectations about the impact of these mandated changes on the distribution of minimum wages. In Section 4 we describe the data set and provide descriptive statistics on changes in the inequality of minimum wages (and wages) over the 1987-1997 period. We form hypotheses as to how the changes in the structure of minimum wages might affect the distribution of wages and test them in Section 4. Section 5 concludes with a discussion of the findings.

\section{Wage Inequality and Liberalization in Costa Rica}

As shown in Gindling and Trejos (2003), earnings inequality in Costa Rica declined from the mid 1970s to the early 1990s and then began to rise. More specifically, Costa Rica experienced a sharp decline in inequality over the 1976-1986 period, a slight decline in the 1987- 
1992 period and a sharp increase in the 1992-1999. Using a three-year moving average, the variance of log earnings fell by -0.113 in the first period, -0.043 in the second period and it rose by 0.072 in the third period. Gindling and Trejos (2003) show that the most important measurable factor underlying this pattern of earnings inequality is the changing returns to education, which fell over the 1976-1987 period and rose thereafter.

The rise in the returns to education and earnings inequality coincides with, but is not inclusive of all, the period of liberalization. Starting in the mid 1980s Costa Rica, along with its Latin American neighbors, began to liberalize trade and open its capital accounts. Costa Rica implemented trade liberalization in an explicitly gradual manner. Although a new Central American Common Market tariff regime was agreed to in 1985, tariff reductions began only in 1987 and were allowed a five-year adjustment period. At the same time, explicit subsidies were put into place for certain exports (in apparel, electronic assembly and non-traditional agriculture). In the 1990s tax credits for non-traditional exports moved toward more high technology products and tourism as subsidies were reduced for labor intensive manufacturing exports. All controls on the capital account were removed by 1993 when the Costa Rican government began to seek aggressively foreign direct investment.

Gindling and Trejos (2003) conclude that the increase in the returns to education from 1987 to 1999 was caused by both supply and demand factors. Robbins and Gindling's (1999) results suggest that relative supply movements were sufficient to explain relative wage changes before 1985 but not after 1987, the beginning of the trade liberalization. They conclude that increase in demand for more educated workers was most-likely due to skill biased technical change, possibly accelerated by skill-enhancing trade following substantial trade liberalization.

Most observers would argue that the increase in inequality is not likely the result of reduction of labor protection since, like many of its Latin American neighbors, Costa Rica did not liberalize the labor market in this period. In fact, following a long tradition of protecting its workers with measures such as universal health care and pension benefits, the government passed a law in 1990 that required parity of wages between men and women. As we show below, in 1987 the government did embark on a gradual reform of the minimum wage structure,

\footnotetext{
${ }^{1}$ See the International Labor Organization, Labour Law and Labour Relations Branch's Briefing Notes at the following website: http://www.ilo.org/public/english/dialogue/govlab/legrel/papers/index.htm.
} 
which we hypothesize counters the wage disequalizing effect of trade liberalization for part of the period.

\section{Minimum Wage Setting}

The 1949 Constitution establishes that every worker has the right to a minimum wage which provides a decent standard of living. Further legislation on wage fixing sees minimum wages as a means of promoting a fair distribution of income. The standard of living objective has been pursued through a continuous process of comparing the purchasing power of minimum wages in relation to different baskets. The income distribution objective has been explicitly pursued in times of severe crises.

According to Law 832, minimum wages should be adjusted every year, the new rates being valid from 1 January. The body responsible for carrying out this work is the National Salaries Council (CNS), a tripartite structure of 9 members elected every four years. ${ }^{2}$ The Council decides the minimum wage increases (by simple majority voting of its members). In addition to this annual fixation, minimum wages can be revised at any time during the year following a request of 5 employers or 15 workers. Although the law institutes this alternative as an exception, it has been used often to compensate for high inflation rates since 1980. Since 1980 minimum wages have been adjusted twice a year, the only exception being 1983 when they were adjusted three times.

In 1987, at the beginning of the period under study, there were 520 separate minimum wage rates, which were set by occupation/skill and industry. As the cumbersome nature of this system was becoming increasingly apparent, some members of the CNS proposed merging minimum wages for similar occupations under more generic titles. This process, which we describe below, started in 1988 and within five years the CNS managed to reduce the number of minimum wages to 72 ; by 1997 they were reduced to the 19 minimum wages that we observe today. $^{3}$

\footnotetext{
${ }^{2}$ Of these three groups, the representatives of the government have the most influence, and the relative bargaining power of the representatives of the government has increased since initiation of the first Structural Adjustment Plan in the mid-1980s. (Interview with José Pablo Carvajal, Director, National Salaries Council, on May 16, 2002.)

${ }^{3}$ For part-time workers the minimum wage is applicable proportionally. In principle, young workers are subject to the same various minimum wage rates as older workers. However, Law 4903 of 1975 enables enterprises to hire entrants to the labor market below 21 years of age for apprenticeships. The objective of this program has been to facilitate the entrance of young workers to the labor market during periods of crisis. Although used extensively in
} 
In 1987, all individuals who worked in the private sector were assigned to a minimum wage category that was defined by a detailed industry and occupational classification. The industrial categories do not correspond to the Standard Industrial Classification of the International Labor Organization (ILO), but the aggregated one-digit categories are similar: agriculture, mining, manufacturing, construction, electricity, commerce, transportation and communication, services. Within each of these categories there could be several subcategories (e.g., in manufacturing there were 44 subcategories.) The occupational/skill categories were specific to the industry, and they too do not correspond to the ILO's standard classification for occupations. However, they roughly corresponded to: supervisor, skilled employees and unskilled workers. For individuals with higher education (professionals) there was a separate set of 14 minimum wages by type of occupation, irrespective of industry of job (e.g., librarians, nurses, accountants, laboratory technicians and drafters). Finally, another minimum wage was set for all workers who had at least a five-year university degree (licenciado), the most common terminal university degree in Costa Rica at the time.

Beginning in 1988, the Ministry of Labor began a gradual process of reducing the number of minimum wage categories for non-university educated workers by eliminating the variation in wages given by the industrial dimension. Specifically, the Ministry identified a broadly-defined occupational (skill) category that was to be harmonized across industries and proceeded gradually to increase the lower(est) minimum wage by a greater amount than the higher(est) minimum wage within each occupational category. For example in January 1995, minimum wages were decreed for only five (one-digit level) industries: mining, manufacturing, construction and electricity were collapsed into one category. The number of wages within each industrial category was also reduced to a total of only 54 wages (for employees with less than a university degree). Over a period of several years, one minimum wage emerged for each broadly-defined skill/occupation, irrespective of industry. By the middle of 1997 the industrial dimension of the minimum wage was completely eliminated.

While the number of minimum wages for the non-university educated workers was being reduced, the number of minimum wages for workers with higher education became more numerous over this period. In 1993 a new minimum wage was set for individuals with two to

the 1980s, the mechanism has not been used much in the 1990s as unemployment rates were low (Rojas and Murillo, 1995). 
three years of university education (diplomados) and for graduates of five-year technical high schools (técnicos). In 1997, another new minimum wage was added for workers with a four-year university degree. Prior to 1993 , the minimum wage applying to workers at these education levels was the same as the minimum wage applying to less-educated workers in the same industry and occupation. Therefore, the addition of minimum wage categories for these workers with higher education should have increased the minimum wage for these workers, increasing the gap between the wages of workers with higher education and workers without higher education, while at the same time reducing the gap between the wages of licenciados and other workers with higher education.

Beginning in June 1997, there were a total of 19 minimum wages, four for nonprofessionals (one each for unskilled workers, semi-skilled workers, skilled workers, specialized workers), nine for professionals and six for special categories (e.g., live-in domestics, stevedores, journalists).

Table 2 summarizes the changes in the level of minimum wages from 1987 to 1997 . It shows that there is a range of rate changes every six months, reflecting the harmonization process. Based on the changes described in this table and in the above paragraphs we would expect: (1) a reduction in the inequality of minimum wages among workers without higher education as the number of minimum wages for this groups is reduced over the 1987-1997 period and the lowest minimum wages were raised more than the highest minimum wages in the harmonization process, (2) an increase in the gap between the minimum wage of workers with higher education and the minimum wage of workers without higher education as the minimum wage for workers with technical degrees, two-year and four-year university degrees are added in 1993-1997, and (3) a reduction in the inequality of minimum wages among workers with higher education in the 1993-1997 period as the minimum wage of workers with technical degrees, twoyear and four-year university degrees increases relative to the wages of workers with a licenciado degree. We first test to whether these patterns indeed exist in the data.

\section{Data}

In our analysis we use annual data on a) legal minimum wages, from decrees published by the Ministry of Labor, and b) workers, from the annual Household Surveys for Multiple 
Purposes carried out by the Costa Rican Institute of Statistics and Census. The household surveys have been conducted in July of every year since 1976 on approximately $1 \%$ of the population. We use data on approximately 10,000 workers each year from 1987 to 1997, the period when minimum wages were simplified.

We start with 1987 data since this is the year that the occupation categories in the household surveys are sufficiently detailed to be able to adequately match the detailed occupation/skill/industry categories in the minimum wage decrees. We use the 3-digit occupational classification available in the household survey, which is not equivalent to the I.L.O. standard classification. For illustration, we present in Table 3 the two-digit occupational classification in the Costa Rican household survey. From careful reading of the minimum wage laws published every year, we assigned the minimum wage corresponding to each of these occupation/skill/industry categories.

The structure of legal minimum wages, weighted by the population to which it applies, is depicted in Figure 1 with histograms of the minimum wage distribution. The figure presents the distribution of real minimum wages (in 1999 colons) among private sector workers who report positive earnings in 1988 (at the start of the simplification) and in 1997 (at the end of the simplification process). Spikes in the distribution of minimum wages represent legal minimum wages that apply to larger proportions of workers. For example, starting from the left (the lowest minimum wage) in the 1988 graph, the first spike is at the minimum wage for domestic servants, who represent approximately $7 \%$ of all workers and to whom applies a legal minimum wage of 123 colones (in 1999 prices) or $\$ 0.43$ (in 1999 U.S. dollars) per hour. There are no minimum wages over a large range of possible wages between the minimum wage for domestic servants and the next minimum wage, which is for unskilled workers (peones and other production workers) in most industries. This second spike represents over $20 \%$ of all workers. Next there is a cluster of many minimum wages that surround two smaller spikes at the minimum wages for operators of machinery and specialized workers (supervisors) in most industries. Finally, at the very right of the distribution of minimum wages (after numerous very small spikes) is a spike at the minimum wage of 578 colones or $\$ 2.00$ per hour (in 1999 prices) set for licenciados (fiveyear university graduates) who represent approximately $2 \%$ of all workers.

The second graph in Figure 1 presents the distribution of (the $\log$ of) real minimum wages among workers who report positive earnings for 1997. A comparison of the graphs for 
1988 with the graphs for 1997 illustrates the changes in the structure of legal minimum wages. As in 1988, the spike at the far left of the 1997 distribution of wages is at the minimum wage for domestic servants (which again represents approximately $7 \%$ of workers) and the second spike occurs at the minimum wage for unskilled workers. However, we can see that the simplification and consolidation process between 1988 and 1997 compressed the distribution of minimum wages around the unskilled wage: while in 1988 the spike at the unskilled minimum wage represented $20 \%$ of workers, in 1997 the minimum wage for unskilled workers applies to $45 \%$ of workers. At the same time that the minimum wages for unskilled workers were being compressed, new minimum wage categories for workers with higher education were added, resulting in several new spikes at higher wage levels, including a spike at the minimum wage for four-year university graduates (4\% of workers) and at the minimum wage for licenciados (2\%).

In Figure 2 we plot the ratio of the average minimum wage for more educated workers to the average minimum wage for less educated workers, where more educated refers to workers with higher education (technical high school and university) and less educated refers to workers with less than a technical high school education. It clearly shows that there was an increase in the gap between the minimum wage of workers with higher education and the minimum wage of workers without higher education as the minimum wage for workers with technical degrees, twoyear and four-year university degrees were added in 1993-1997.

In Figure 3 we plot the standard deviation of the $\log$ of minimum wages, SD(lnMW), for all workers and by more or less education. It shows that, as expected: (1) There was a reduction in the $\mathrm{SD}(\operatorname{lnMW})$ among workers without higher education as the number of minimum wages for this groups is reduced over the 1987-1997 period and (2) there was a reduction in the SD(lnMW) among workers with higher education in 1993-1997 as the minimum wage of workers with technical degrees, two-year and four-year university degrees increases relative to the wages of workers with a licenciado degree. Facts (1) and (2) caused the $\operatorname{SD}(\ln M W)$ for all workers to fall from 1987 to 1992 but the increase in the gap between the more and less educated, shown in Figure 2, caused the SD(lnMW) for all workers to rise from 1992-1997.

The plots in Figure 4 of the standard deviation of the log of wages shows that as the dispersion of minimum wages changed, so did the dispersion or inequality of actual wages. Figures 2-4 and the summary measures provided in Appendix Table A1 appear to indicate that changes in the inequality of legal minimum wages are correlated with the change in the 
inequality of actual wages. For example, as the inequality of minimum wages for workers with and without higher education fell from 1987 to 1997 , so did the inequality of actual wages. Further, as the standard deviation of the log of minimum wages for all workers fell from 1987 to 1992, so did the standard deviation of the log of actual wages for all workers. Then, as the standard deviation of minimum wages rose from 1987 to 1992, so did the standard deviation of actual wages. Note that changes in the inequality of actual hourly wages do not appear to be closely correlated with the change in the average or minimum legal minimum wage.

These results suggest four questions (hypotheses): (1) Did the increase in the gap between the minimum wages of workers with and without higher education cause the gap between the actual wages of workers with and without higher education to increase (and therefore cause an increase in wage inequality)? (2) Did the reduction in the inequality of minimum wages for workers without higher education cause a reduction in the inequality of actual wages for these workers? (3) Did the reduction in the inequality of minimum wages for workers with higher education cause a reduction in the inequality of actual wages for these workers? (4) Did changes in the minimum minimum wage cause changes in the dispersion of actual wages? We test these hypotheses in the next section.

\section{Measuring the Effects of Changes in Minimum Wage Structure on Wage Inequality}

To test the above hypotheses, we pool the individual data on all salaried workers in the private sector for the 1987 to 1997 years and create panel data for seven industries. ${ }^{4}$ Using this data set, we estimate the following equation with industry fixed effects:

$$
\ln \left(\bar{W}_{i t}^{\text {Skilled }} / \bar{W}_{i t}^{\text {Unskilled }}\right)=\alpha_{o}+a_{1} \ln \left(\bar{M} \bar{W}_{i t}^{\text {Skilled }} / \bar{M} \bar{W}_{i t}^{\text {Unskilled }}\right)+\sum_{t=1}^{T} \gamma_{t} Y R_{t}+\mu_{i t}
$$

where the dependent variable, $\ln \left(\bar{W}_{i t}\right.$ Skilled $\left./ \bar{W}_{i t}^{\text {Unskilled }}\right)$, is the $\log$ of the ratio of the average real hourly wage of skilled workers to the average real wage of unskilled workers in industry $i$ at time $t(1987 \ldots 1997) ; \ln \left(\overline{M W_{i t}}\right.$ Skilled $\left./ \overline{M W_{i t}^{\text {Unskilled }}}\right)$ is the $\log$ of the ratio of the average minimum wage for skilled workers to the average minimum wage for unskilled workers in each industry in each year. We use the term "skilled" to refer to workers with higher education (technical high school and above) and by "unskilled" we refer to workers without higher education. The 
coefficient $\alpha_{1}$ is an estimate of the impact of the ratio of the minimum wages on the ratio of actual wages of skilled to unskilled workers. A positive and statistically significant coefficient $\left(\alpha_{1}\right)$, would provide evidence in support of the first hypothesis, that the increase in the gap between the minimum wages of workers with and without higher education causes the gap between the actual wages of workers with and without higher education to increase. We estimate the equation using industry fixed effects to control for unobserved differences across industries. To control for year-specific factors such as changes in aggregate supply and aggregate demand and the timing of minimum wage changes, we include a dummy variable for each year, $Y R_{t}$.

The results of the estimation of equation (1) are reported in Table 4 . We find that the coefficient $\alpha_{l}$ is positive and statistically significant (specifically, it is equal to 0.632 with a standard error of 0.156). Thus, our results provide evidence in support of the hypothesis that the increase in the gap between the minimum wages of workers with and without higher education caused the gap between the actual wages of workers with and without higher education to increase.

To test hypotheses 2 and 3, we estimate the following equation, separately for workers with and without higher education and for all workers combined:

$$
S D\left(\ln W_{i t}\right)=\beta_{o}+\beta_{l}\left[S D\left(\ln M W_{i t}\right)\right]+\sum_{t=l}^{T} \gamma_{t} Y R_{t}+\mu_{i t},
$$

where the dependent variable is a measure of inequality, i.e., the standard deviation of the log of the real hourly wage (in 1999 colones) in industry $i$ at time $t(1987 \ldots 1997) ; S D\left(\ln M W_{i t}\right)$ is the standard deviation of the log of real minimum wages in each industry in each year. We include year dummies and estimate the equation with industry fixed effects to control for unobserved differences between industries. The coefficient $\beta_{l}$ is an estimate of the impact of changes in the variance in the legal minimum wage on the variance of actual wages. A positive and significant coefficient $\beta_{l}$ would provide evidence in support of the hypothesis that changes in the inequality of minimum wages cause changes in the inequality of actual wages.

The results of the estimates of equation (2) are also reported in Table 4. In the equation estimated using data on workers without higher education, the coefficient $\beta_{1}$ is positive $(0.432)$

\footnotetext{
${ }^{4}$ Public sector workers are excluded from the analysis since their wages are governed by a different set of decrees. The seven industries are: agriculture, manufacturing, construction, commerce, transportation, communication, and services.
} 
and significant. In the equation estimated with data on workers with higher education, the coefficient $\beta_{l}$ is also positive (0.817) and significant. These results provide evidence in support of the hypothesis that the reduction in the inequality of minimum wages for workers with and without higher education caused a reduction in the inequality of actual wages for each of these categories workers. In the equation estimated using data on both workers without and without higher education, the coefficient $\beta_{l}$ is positive $(0.245)$ but not significant.

The literature on the impact of minimum wages on inequality has generally analyzed the impact of changes in the "minimum minimum wage" (rather than the dispersion of minimum wages) on wage inequality. The argument generally made is that an increase in the minimum minimum wage will increase the wages of the lowest-paid workers, and therefore reduce the inequality of wages by truncating the left tail of the distribution. To test this hypothesis, we estimate an equation similar to equation (2), but that includes the log of real minimum minimum wage $\left(\ln M i n M W_{i t}\right)$ as an independent variable rather than the standard deviation of the $\log$ of minimum wages:

$$
S D\left(\ln W_{i t}\right)=\beta_{0}+\beta_{1} \ln \operatorname{MinM} W_{i t}+\sum_{t=1}^{T} \gamma_{t} Y R_{t}+\mu_{i t} .
$$

A negative and significant coefficient on the real minimum minimum wage variable would provide evidence in support of the hypothesis that an increase in the minimum minimum wage reduces inequality in actual wages. We estimate this equation with data on all workers and less educated workers and present the results in Table 4. In both cases, the coefficient on the real minimum minimum wage is positive and insignificant. These findings allows us to reject the hypothesis that an increase in the minimum minimum wage causes a reduction in inequality in actual wages in Costa Rica.

Finally, to examine the relative impacts of changes in the dispersion and the levels of minimum wages, we estimate an equation that includes both the standard deviation of the $\log$ of the minimum wage and the real value of the minimum minimum wage as independent variables:

$$
S D\left(\ln W_{i t}\right)=\beta_{0}+\beta_{1} S D\left(\ln M W_{i t}\right)+\beta_{2} \ln M i n M W_{i t}+\sum_{t=1}^{T} \gamma_{t} Y R_{t}+\mu_{i t} .
$$

In Table 4, we present the coefficient estimates of $\beta_{1}$ and $\beta_{2}$ from estimating equations (4) using data for all workers and for less educated workers, separately. These estimated 
coefficients confirm our previous results. That is, they provide evidence that changes in the dispersion of minimum wages are positively and significantly correlated with the changes in the dispersion of the wages of workers without higher education, while changes in the real minimum minimum wage do not have statistically significant effects on the dispersion of wages. This finding is important since many studies use the level of the minimum wage as an explanatory factor in their analysis of the rising skilled to unskilled wage ratio over time (e.g., Bell, 1997 and Cortez, 2001). Whereas the minimum wage can increase the average wage, it is not clear that it should reduce dispersion. And when only one minimum wage is used in cases when there are multiple minimum wage (as in the case of studies of Mexico, e.g. Bell, 1997), then it is not surprising that there are no significant results.

\section{Conclusions}

In summary, we show that Costa Rica experienced rising wage inequality in the 1990s, during the period it opened its economy to global forces. We know from Robbins and Gindling (1999) that the rise in the relative wages of more skilled workers in Costa Rica could be attributed in part to rising demand for more skilled workers due to trade liberalization. Work by Gindling and Trejos (2003) finds a number of other factors that can also help explain rising earnings inequality (including changes in the levels or supply of education) but notes there is a large part of the change in inequality that they cannot explain with such variables as education, gender, region, hours worked or job characteristics.

In this paper, we test whether minimum wage legislation is part of the missing story. Our examination of Costa Rica's complex minimum wage structure and its dynamics suggested three

hypotheses: (1) The increase in the gap between the minimum wages of workers with and without higher education cause the gap between the actual wages of workers with and without higher education to increase (and therefore cause an increase in wage inequality); (2) The reduction in the inequality of minimum wages for workers without higher education cause a reduction in the inequality of actual wages for these workers; and (3) The reduction in the inequality of minimum wages for workers with higher education cause a reduction in the inequality of actual wages for these workers. We find that the evidence supports each of these three hypotheses.

The level of minimum MW was not found to be important in affecting the dispersion of wages. It was expected that the minimum minimum would truncate the left tale of the earnings 
distribution and as such lower inequality. However, in a complex system such as that in Costa Rica (or Mexico and Argentina), it is not clear the either the minimum MW or the average MW should affect the distribution since there are a multitude of wages that can affect the distribution at higher levels. Nevertheless, since many studies have used this variable in trying to explain changes in earnings inequality, we thought it worthwhile testing for it as well.

In sum, the structure of minimum wages matters, and we found it contributes to wage inequality in Costa Rica. This suggests that countries with an interest in mitigating inequality arising from trade liberalization have the levers to do so with a multiple minimum wage policy. In Costa Rica, the reduction in the inequality of legal minimum wages from 1987 to 1992 contributed to a decline in actual wage inequality, mitigating the disequalizing impact of the trade liberalization (found by Robbins and Gindling, 1999). However, when the addition of legal minimum wages for university-educated workers in 1993 increased the gap between the minimum wages of worker with and without higher education, changes in the structure of minimum wages contributed to an increase in wage inequality. 


\section{References}

Bell, L. (1997) "The Impact of Minimum Wages in Mexico and Colombia," Journal of Labor Economics, 15(3): S102-S134.

Berman, E., J. Bound and S. Machin (1998) "Implications of Skill-biased Technological Change: International Evidence," Quarterly Journal of Economics, 113 (4): 1245-1280.

Card, D. and J. DiNardo (2002) "Skill-Biased Technological Change and Rising Wage Inequality: Some Problems and Puzzles," NBER Working Paper 8769.

Cortez, W. W. (2001) “What is Behind Wage Inequality in Mexico?" World Development, 29(11): 1905-2001.

DiNardo, J., N. M. Fortin and T. Lemieux (1996) "Labor Market Institutions and the Distribution of Wages, 1973-1992: A Semi parametric Approach.” Econometrica, 64(5): 1001-1044.

Feenstra, R. and Hanson (1996) "Globalization, Outsourcing and Wage Inequality," American Economic Review, 86 (2): 240-245.

(1997) "Foreign Direct Investment and Relative Wages: Evidence from Mexico's Maquiladoras," Journal of International Economics, 42 (?): 371-393.

Gindling, T.H. and D. Robbins (2001) "Patterns and Sources of Changing Wage Inequality in Chile and Costa Rica During Structural Adjustment," World Development, 29(4): 725-745.

Gindling, T.H. and J.D. Trejos (2003) "Accounting for Changing Earnings Inequality in Costa Rica, 1980-1999," University of Maryland Baltimore Department of Economics Working Paper 03-108.

Pavnick, N., A. Blom, P. Goldberg, and N. R. Schady (2002) "Trade Liberalization and Wage and Inequality in Brazil", unpublished paper, the World Bank.

Robbins, D. and T. H. Gindling (1999)“Trade Liberalization and the Relative Wages of MoreSkilled Workers in Costa Rica, Review of Development Economics, 3(2): 140-154.

Rojas, G. and Murillo (1995) "El sistema de salarios mínimos en costa Rica. Origen y evolución," I.L.O, unpublished report.

Skuratowicz, A. (2000) "Effects of FDI on Wage Inequalities in Poland: Theory and Evidence" unpublished paper, Catholic University of Leuven.

$\mathrm{Wu}, \mathrm{X}$. (2001) "The Impact of Foreign Direct Investment on the Relative Return to Skill," Economics of Transition, 9(3): 695-715. 
Table 1: Countries with More Than One Minimum Wage in the Private Sector

\begin{tabular}{|c|c|c|c|c|c|c|c|}
\hline & COUNTRY & REGION & $\mathrm{OCC}$ & IND & $\begin{array}{c}\text { Trainee, } \\
\text { Appren. or } \\
\text { Youth }\end{array}$ & $\begin{array}{l}\text { Marital } \\
\text { Status }\end{array}$ & $\begin{array}{c}\text { Job } \\
\text { Tenure } \\
\text { or }\end{array}$ \\
\hline 1 & Australia & & $\mathrm{X}$ & $\mathrm{X}$ & & & \\
\hline 2 & Argentina & $\mathrm{X}$ & & & & & \\
\hline 3 & Barbados & & $\mathrm{X}$ & & & & \\
\hline 4 & Belize $^{*}$ & & & $\mathrm{X}$ & & & \\
\hline 5 & Benin & & $\bar{X}$ & & & & \\
\hline 6 & Brazil (before 1984) & $\bar{X}$ & & & & & \\
\hline 7 & Burma $^{* *}$ & & & $\mathrm{X}$ & & & \\
\hline 8 & Burundi & $\mathrm{X}$ & $\mathrm{X}$ & & & & \\
\hline 9 & Cambodia $^{* *}$ & $\mathrm{X}$ & & $\mathrm{X}$ & & & \\
\hline 10 & Canada & $\mathrm{X}$ & & & & & \\
\hline 11 & Central African Republic & & $\mathrm{X}$ & $\mathrm{X}$ & & & \\
\hline 12 & China $^{* *}$ & $\mathrm{X}$ & & & & & \\
\hline 13 & Cuba & & $\bar{X}$ & & & & \\
\hline 14 & Czech Republic & & $\mathrm{X}$ & & $\mathrm{X}$ & & \\
\hline 15 & Equitorial Guinea $^{* *}$ & & & $\mathrm{X}$ & & & \\
\hline 16 & Ethiopia** & & & $\mathrm{X}$ & & & \\
\hline 17 & Fiji* & & & $\mathrm{X}$ & & & \\
\hline 18 & Finland & & & $\mathrm{X}$ & & & \\
\hline 19 & The Gambia & & & $\mathrm{X}$ & & & \\
\hline 20 & Greece** & & $\mathrm{X}$ & & & $\mathrm{X}$ & $\mathrm{X}$ \\
\hline 21 & Guinea-Bissau & & $\mathrm{X}$ & & & & \\
\hline 22 & Honduras & $\bar{X}$ & $\mathrm{X}$ & & & & \\
\hline 23 & India & $\mathrm{X}$ & & $\mathrm{X}$ & & & \\
\hline 24 & Indonesia & $\mathrm{X}$ & & & & & \\
\hline 25 & Iran & $\mathrm{X}$ & & $\mathrm{X}$ & & & \\
\hline$\overline{26}$ & Italy & & & $\mathrm{X}$ & & & \\
\hline 27 & Ivory Coast & & $\mathrm{X}$ & & & & \\
\hline 28 & Japan & $\mathrm{X}$ & & $\mathrm{X}$ & & & \\
\hline 29 & Jordan & & & & & & \\
\hline 30 & Luxembourg & & & & $\mathrm{X}$ & $\mathrm{X}$ & $\mathrm{X}$ \\
\hline 31 & Malawi* & $\mathrm{X}$ & & & & & \\
\hline 32 & Malaysia** & $\mathrm{X}$ & & $\mathrm{X}$ & & & \\
\hline 33 & Mauritius & & $\mathrm{X}$ & $\mathrm{X}$ & & & \\
\hline 34 & Mexico & $\bar{X}$ & $\mathrm{X}$ & & & & \\
\hline 35 & Morocco* & & & $\mathrm{X}$ & & & \\
\hline 36 & Mozambique* & & & $\mathrm{X}$ & & & \\
\hline 37 & Nepal & & $\mathrm{X}$ & & $\mathrm{X}$ & & \\
\hline 38 & Nicaragua & & & $\mathrm{X}$ & & & \\
\hline 39 & Niger & & & $\mathrm{X}$ & & & \\
\hline 40 & Pakistan & $\mathrm{X}$ & & & & & \\
\hline 41 & The Philippines & $\bar{X}$ & & $\mathrm{X}$ & & & \\
\hline 42 & Rwanda & & $\mathrm{X}$ & & & & \\
\hline 43 & Spain & & & & $\mathrm{X}$ & & \\
\hline 44 & Sri Lanka & & & $\mathrm{X}$ & & & \\
\hline 45 & Swaziland & & $\mathrm{X}$ & & & & \\
\hline 46 & Togo & & $\mathrm{X}$ & & & & \\
\hline & TOTAL & 16 & 17 & 22 & 4 & 2 & 2 \\
\hline
\end{tabular}

* Only 2 minimum wages.

** Does not apply to all regions, occupations, or sectors.

Sources:International Labor Organization, Labour Law and Labour Relations Branch's Briefing Notes at the following website: http://www.ilo.org/public/english/dialogue/govlab/legrel/papers/index.htm

Index of Economic Freedom, 2004. The Heritage Foundation/Wall Street Journal $<$ www.heritage.org/research/features/index/countries.html $>$

OECD, 1998. "Making the Most of the Minimum: Statutory Minimum Wages, Employment and Poverty," in Employment Outlook, 1998.

Wailes, Nick and Russell D. Lansbury, 1999. "Collective bargaining and flexibility: Australia," ILO IFP/DIALOGUE Working Papers Series, 1999. 


\section{Table 2: Summary of Changes in Legal Minimum Wages, Costa Rica 1987 - 1997}

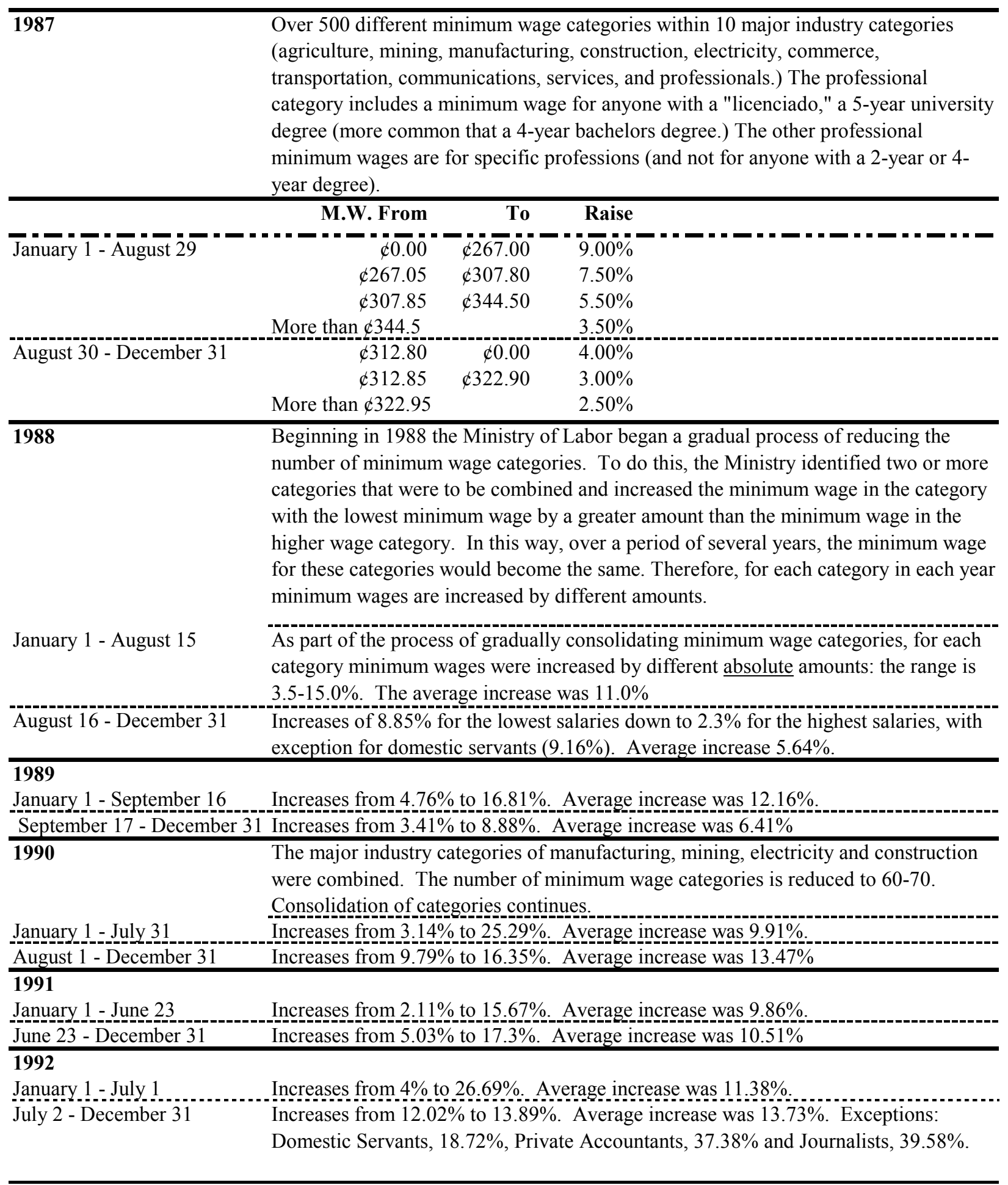


Several categories are added for those with higher education. In addition to the already existing minimum wage for "licenciados," legal minimum wages are now set for those with 2-3 years of university education ("diplomados" or "tecnicos") and for graduates of 5-year technical high schools.

\begin{tabular}{|c|c|}
\hline & \\
\hline July 27 - December 31 & Increases from $4.65 \%$ to $6.37 \%$. Average increase was $5.02 \%$ \\
\hline \multicolumn{2}{|l|}{1994} \\
\hline \multirow[t]{2}{*}{ January 1 - July 30} & Increases of \\
\hline & Other Activities \\
\hline \multirow[t]{4}{*}{ July 31 - December 31} & Unskilled ag. labor in Palm Oil \\
\hline & Bus Drivers \\
\hline & "Coyol" harvesters \\
\hline & All other activities \\
\hline \multicolumn{2}{|l|}{1995} \\
\hline \multirow[t]{2}{*}{ January 1 - August 9} & "Coyol" harvesters \\
\hline & all other activities \\
\hline \multicolumn{2}{|l|}{ August 10 -December 31} \\
\hline \multicolumn{2}{|l|}{1996} \\
\hline & Increases from $38.08 \%$ to $17.78 \%$. Average increase was $8.35 \%$. \\
\hline \multicolumn{2}{|r|}{ Increases from $8.54 \%$ to $7.95 \%$. Average increase was $8.05 \%$} \\
\hline \multirow[t]{8}{*}{1997} & \multirow{8}{*}{$\begin{array}{l}\text { The major industry categories were combined into one that specifically includes } \\
\text { agriculture, mining, manufacturing, construction, commerce, tourism, services, } \\
\text { transport, and warehousing. Within this combined category four minimum wages are } \\
\text { set, for unskilled workers, semi-skilled workers, skilled workers and specialized } \\
\text { workers (supervisors.) Two other major categories remained: professionals and } \\
\text { "specials." "Specials" included a minimum wage for domestic servants. Within the } \\
\text { professionals category a minimum wage was added for workers with a 4-year } \\
\text { university degree. These changes resulted in only } 19 \text { different minimum wages being } \\
\text { set in } 1997 .\end{array}$} \\
\hline & \\
\hline & \\
\hline & \\
\hline & \\
\hline & \\
\hline & \\
\hline & \\
\hline January 1 - July 4 & Increases from $38.08 \%$ to $17.78 \%$. Average increase was $8.35 \%$. \\
\hline July 5 - December 31 & Increases from $8.54 \%$ to $7.95 \%$. Average increase was $8.05 \%$ \\
\hline
\end{tabular}

Sources: Ministry of Labor and Social Security, National Salary Council, Department of Salaries, and interviews with Jose Pablo Carvajal (Director, National Salary Council), July 14, 2003 and Orlando Garcia (Planning Directorate, Ministry of Labor), July 15, 2003. 
Table 3: Occupation Codes used by the Costa Rica's National Statistic and Census Institute for the Multi-purpose Housing Surveys, from 1987 to 2000.

\begin{tabular}{|c|c|}
\hline Groups & Description \\
\hline $\mathbf{0}$ & Professionals and technicians \\
\hline 00 & $\begin{array}{l}\text { Professionals and technicians in: architecture, urbanism, technical drawing, engineering and } \\
\text { industrial engineering technology. }\end{array}$ \\
\hline 01 & $\begin{array}{l}\text { Professionals and technicians in: chemistry, physic, astronomy, geology, bacteriology and } \\
\text { industrial laboratories. }\end{array}$ \\
\hline 02 & $\begin{array}{l}\text { Professionals and technicians in: agronomy and veterinary medicine, biology, natural sciences, } \\
\text { and agricultural technology. }\end{array}$ \\
\hline 03 & $\begin{array}{l}\text { Professionals and technicians in: medicine, surgery, dentistry, pharmacy, medic technology, } \\
\text { and paramedic and health activities. }\end{array}$ \\
\hline 04 & $\begin{array}{l}\text { Professionals and technicians in: arts, literature, sports, recreation, communication, advertising, } \\
\text { organization and social welfare. }\end{array}$ \\
\hline 05 & Professionals and technicians in: religious and cult activities. \\
\hline 06 & Professionals and technicians in: teaching and research. \\
\hline 07 & $\begin{array}{l}\text { Professionals and technicians in: mathematics and statistics, economics, business, accounting } \\
\text { and social sciences. }\end{array}$ \\
\hline 08 & Professionals and technicians in: law and jurisprudence. \\
\hline 09 & Professionals and technicians in: maritime, fluvial and air transport and communications. \\
\hline 1 & Directors and general managers \\
\hline 10 & $\begin{array}{l}\text { Directors and senior managers in the public administration (executive, legislative and judicial } \\
\text { powers). }\end{array}$ \\
\hline 11 & $\begin{array}{l}\text { Directors and managers in government institutions with total or partial administrative } \\
\text { independency and private enterprises: in agricultural and industrial production and trade. }\end{array}$ \\
\hline 12 & $\begin{array}{l}\text { Directors and general managers in government institutions with total or partial administrative } \\
\text { independency and private enterprises in the service industries. }\end{array}$ \\
\hline 2 & Office clerks in the government and private enterprises \\
\hline 20 & $\begin{array}{l}\text { Office clerks and financial accountant employees in the government (central, regional, local } \\
\text { levels) and private enterprises. }\end{array}$ \\
\hline 21 & Accounting and budget employees. \\
\hline 22 & Employees in secretarial activities and transcription and reproduction of texts. \\
\hline 23 & Operators of computers and accounting equipments. \\
\hline 24 & Employees in supervision, delivery and control of transport and communication services. \\
\hline 25 & Employees in mail and message distribution \\
\hline 26 & $\begin{array}{l}\text { Employees in the operation of radiotelephony, radiotelegraphy, and telecommunication } \\
\text { equipment. }\end{array}$ \\
\hline 27 & Administrative employees in other services. \\
\hline 3 & Traders, retailers, wholesalers and salespersons \\
\hline 30 & Retailers and wholesalers. \\
\hline 31 & Retail salespersons and salesmen on the streets. \\
\hline 32 & Sale representatives - wholesale and manufacturing. \\
\hline 33 & Other salespersons and sale agents, traders and commission agents \\
\hline 4 & Crop and animal farmers, and agricultural workers. \\
\hline
\end{tabular}




\begin{tabular}{|c|c|}
\hline 40 & Agricultural Overseers \\
\hline 41 & Crop and animal farmers (owners) \\
\hline 42 & Agricultural workers \\
\hline 43 & Fishers \\
\hline 44 & Hunters and other workers in hunting. \\
\hline 45 & Forestry workers \\
\hline 5 & Occupations related to driving, operating and controlling of transportation vehicles. \\
\hline 50 & Drivers of terrestrial transport vehicles. \\
\hline 51 & Railway conductor and stokers. \\
\hline 52 & Conductors and crew of ships and others. \\
\hline 53 & Operators of equipment of transit signals and controls. \\
\hline 6 & $\begin{array}{l}\text { Occupations in craft and manufacturing production of textiles and clothing. Also, } \\
\text { occupations in carpentry, bricklaying, painting, plumbing, mechanic, and electricity. }\end{array}$ \\
\hline 60 & Textile workers. \\
\hline 61 & Clothing production workers (except footwear, leather articles and related goods). \\
\hline 62 & Shoemakers, saddlers and related footwear workers \\
\hline 63 & Carpenters, cabinetmakers and related wood workers. \\
\hline 64 & Bricklayers, ceiling installers and other construction workers. \\
\hline 65 & $\begin{array}{l}\text { Painters of construction, vehicles, machinery, etc. (except painters and decorators of glass and } \\
\text { ceramic). }\end{array}$ \\
\hline 66 & Plumbers or other installers of pipes and metallic structures and welders in general. \\
\hline 67 & Electricians. Operators and repairers of electric and electronic installations and equipment. \\
\hline 68 & $\begin{array}{l}\text { Mechanics and repairers of machinery in different sectors: agriculture, manufacture, } \\
\text { construction and transport. }\end{array}$ \\
\hline 69 & $\begin{array}{l}\text { Watchmakers, opticians, mechanics of precision; jewelers, silversmiths and related workers of } \\
\text { jewels and objects made of precious metals. }\end{array}$ \\
\hline 7 & $\begin{array}{l}\text { Occupations in craft and manufacturing production in graphic, chemical, mining, metal } \\
\text { smelting, food product and beverage, ceramic, leather, tobacco and other product } \\
\text { industries. }\end{array}$ \\
\hline 70 & Crafts persons and operators of graphic machines. \\
\hline 71 & Miners, mining stonecutters, and operators of mining extraction machinery \\
\hline 72 & Smelters, rolling mill operators and workers related to metal treatments. \\
\hline 73 & Ceramists, potters and glass object producers. \\
\hline 74 & $\begin{array}{l}\text { Workers and operators of machinery in chemical, wood, paperboard and corrugated paper } \\
\text { industries. }\end{array}$ \\
\hline 75 & Workers and operators of machinery in food product and beverage industries. \\
\hline 76 & Workers in tobacco transformation and cigarette production. \\
\hline 77 & Workers in tanneries and workers related to transformation of skins and leathers. \\
\hline 78 & Other crafts persons and machine operators. \\
\hline 8 & Occupations in packing, loading, and storage \\
\hline 80 & Workers in packing, loading and storage \\
\hline 9 & Personal services and related services. \\
\hline 90 & Workers in vigilance, protection and security. \\
\hline 91 & Cooks, maids, cleaners and occupations in food and beverage service. \\
\hline 92 & Workers in laundry and ironing. \\
\hline 93 & Doormen and building cleaners and managers. \\
\hline 94 & Estheticians \\
\hline 95 & Other workers in personal services. \\
\hline 98 & People working in unidentified occupations. \\
\hline
\end{tabular}


Table 4: Regressions of Inequality of Wages on Inequality and Level of Minimum Wages*

\begin{tabular}{|c|c|c|c|c|}
\hline \multirow[b]{2}{*}{ Sample: } & \multirow[b]{2}{*}{ Dependent Variable: } & \multicolumn{3}{|c|}{ Independent Variables: } \\
\hline & & $\begin{array}{c}\text { Minimum Wage } \\
\text { Ratio** }^{* *}\end{array}$ & $\begin{array}{c}\text { St. Dev. of Log } \\
\text { of Real MW }\end{array}$ & $\begin{array}{c}\text { Real } \\
\text { Min. MW }\end{array}$ \\
\hline \multirow[t]{4}{*}{ All Workers } & (1) Wage Ratio** & $\begin{array}{l}0.632^{\mathrm{a}} \\
(0.156)\end{array}$ & - & - \\
\hline & (2) St. Dev. of In real wage & - & $\begin{array}{r}0.254 \\
(0.205)\end{array}$ & - \\
\hline & (3) St. Dev. of In real wage & - & - & $\begin{array}{r}0.0001 \\
-0.0002\end{array}$ \\
\hline & (4) St. Dev. of In real wage & - & $\begin{array}{r}0.253 \\
(0.207) \\
\end{array}$ & $\begin{array}{r}0.0001 \\
(0.0002) \\
\end{array}$ \\
\hline \multirow[t]{4}{*}{ Less Educated Workers } & (5) St. Dev. of In real wage & - & $\begin{array}{c}0.432^{a} \\
(0.166)\end{array}$ & - \\
\hline & (6) St. Dev. of In real wage & - & - & 0.0001 \\
\hline & & & & -0.0002 \\
\hline & (7) St. Dev. of In real wage & - & $\begin{array}{r}0.438^{a} \\
(0.168) \\
\end{array}$ & $\begin{array}{r}0.0001 \\
(0.0002) \\
\end{array}$ \\
\hline Higher Educated Workers & (8) St. Dev. of In real wage & - & $\begin{array}{c}0.817^{a} \\
(0.256)\end{array}$ & - \\
\hline
\end{tabular}

a=Significant at the $1 \%$ confidence level

$c=$ Significant at the $10 \%$ confidence level

*The regressions use 77 data points (10 years of data on 7 industries) and is estimated with industry and time fixed effects.

**The ratio of the wage (or minimum wage) of workers with higher education to the wage (or minimum wage) of workers without a higher education. 
Figure 1: The Distribution of Legal Minimum Wages Among Workers, 1988 and 1997
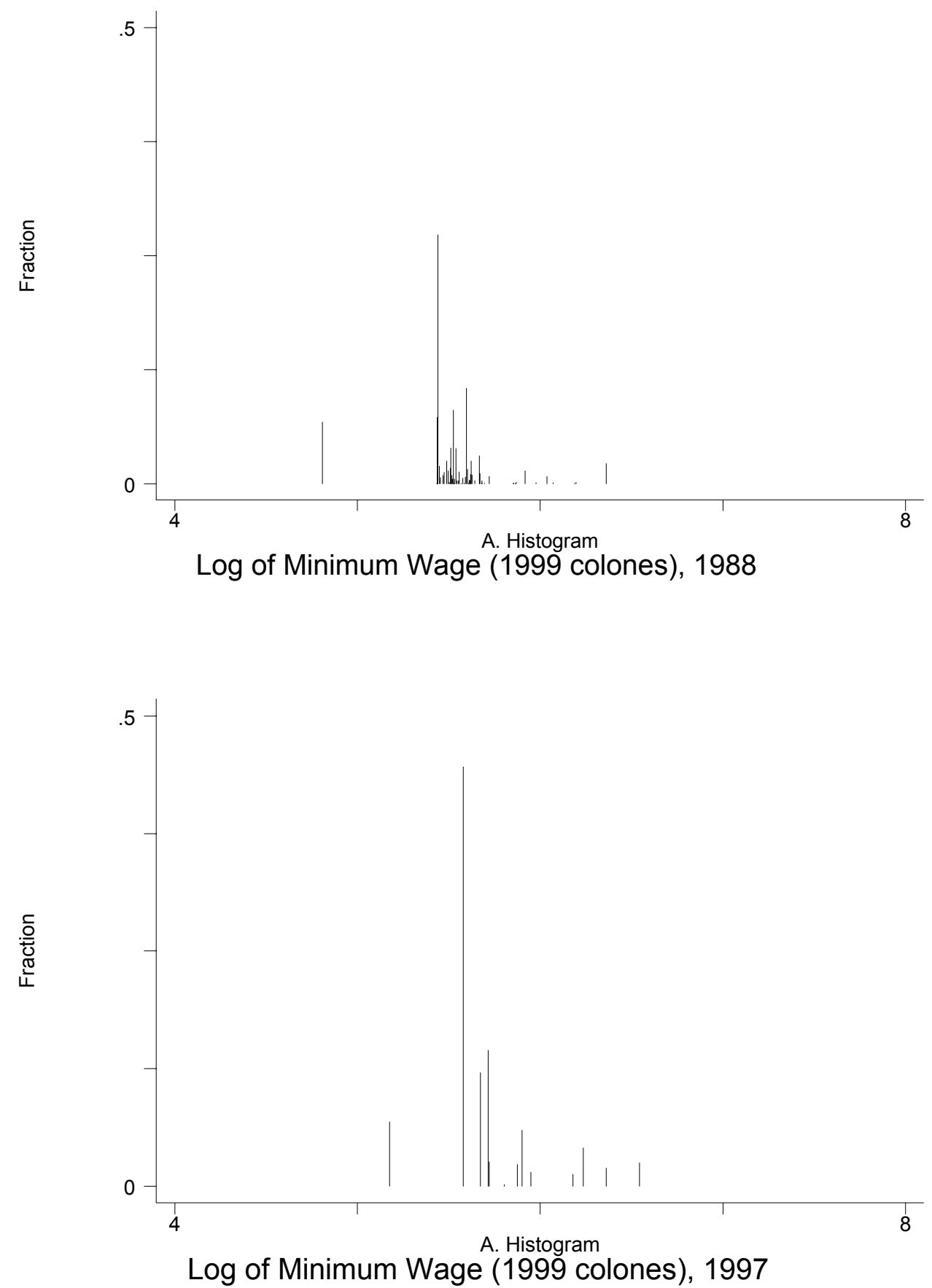
Figure 2: Average MW of Higher Educated Workers to Less Educated Workers

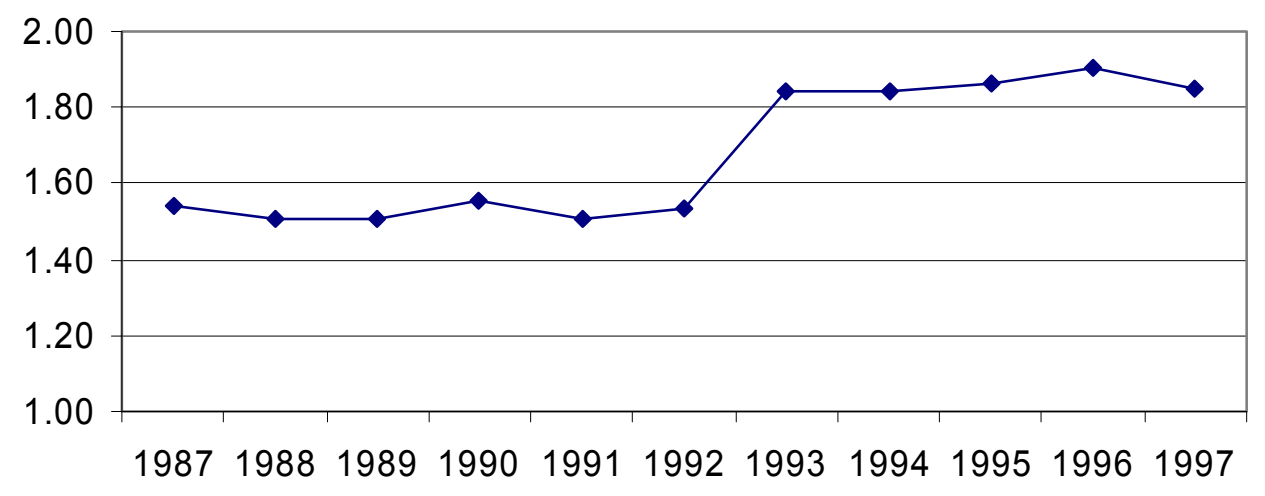


Figure 3: Standard Deviation of the Log of Minimum Wages

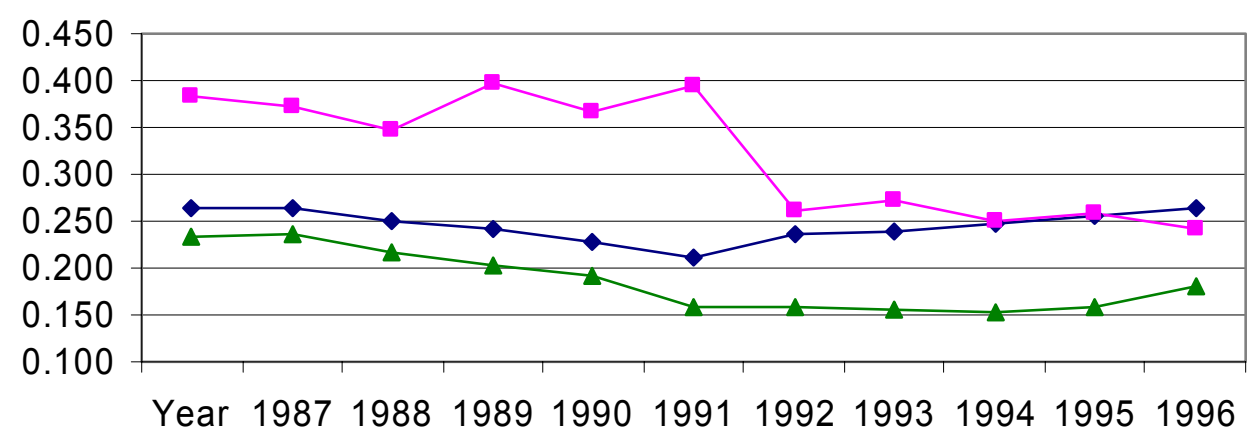

$\multimap$ All $\longrightarrow$ w/ High Ed $\multimap$ w/out High Ed

Figure 4: Standard Deviation of the Log of Wages

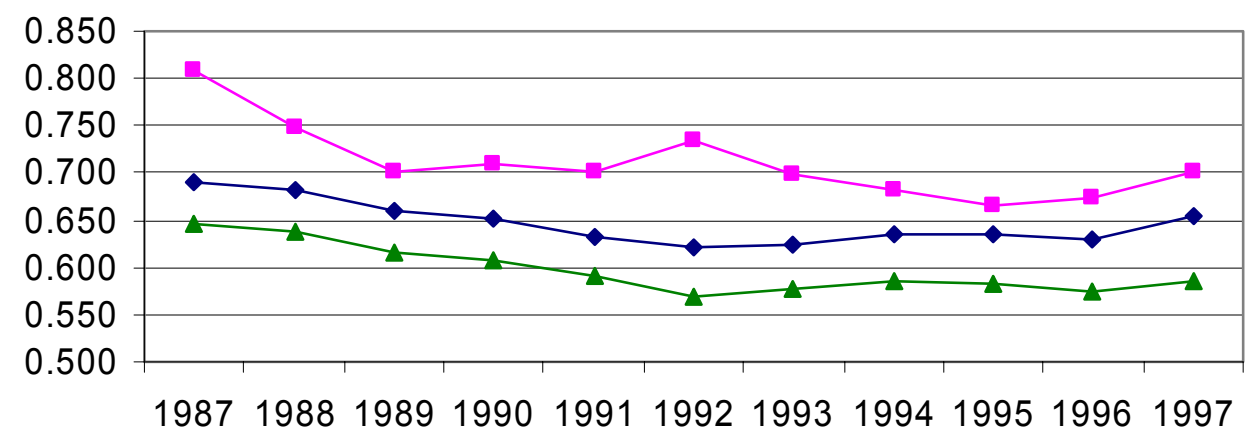

$\multimap$ All $\rightarrow-$ More Educ. $\longleftarrow$ Less Educ. 


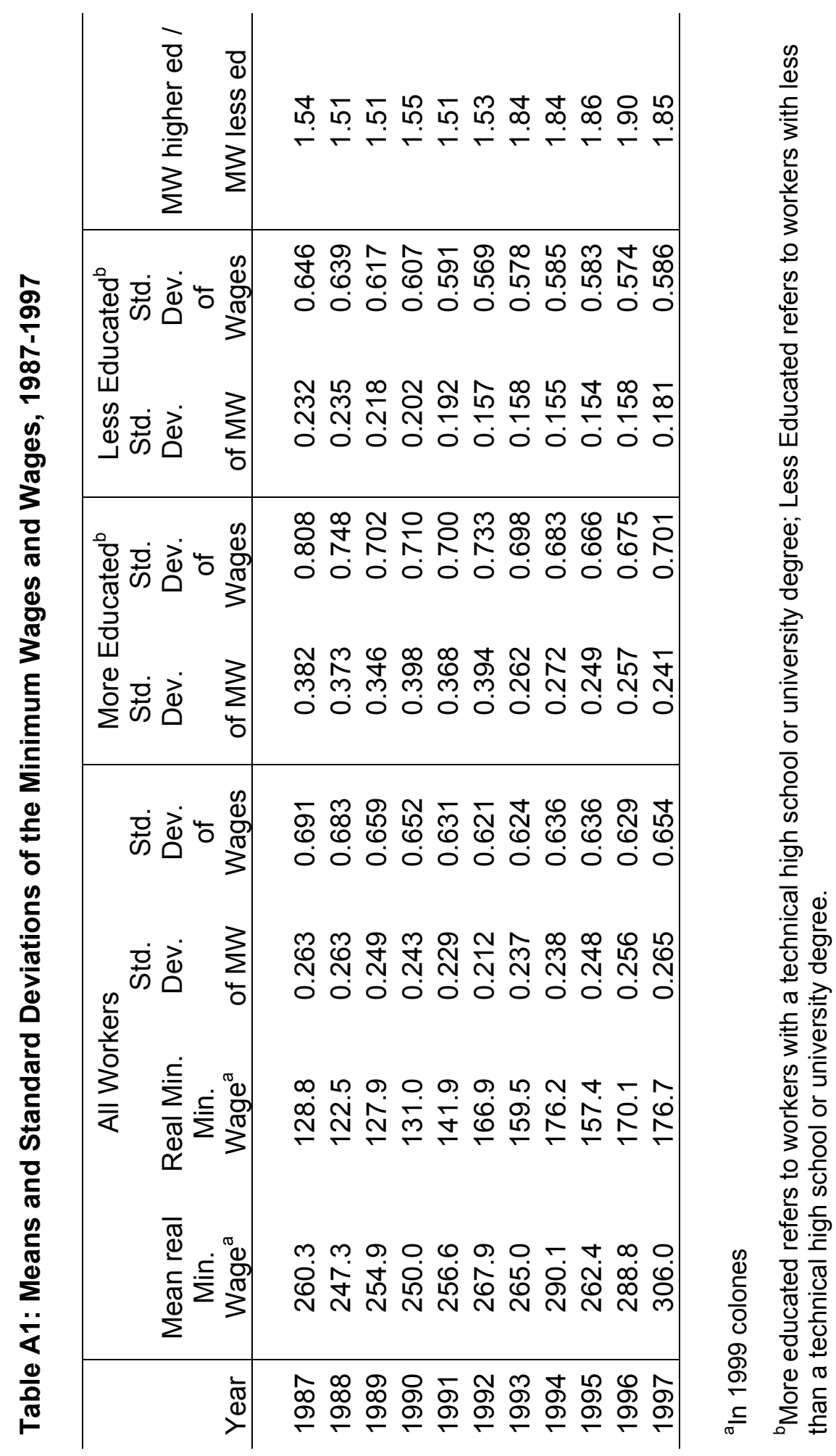




\section{DAVIDSON INSTITUTE WORKING PAPER SERIES - Most Recent Papers}

The entire Working Paper Series may be downloaded free of charge at: www.wdi.bus.umich.edu

CURRENT AS OF 5/20/04

\begin{tabular}{|c|c|c|}
\hline Publication & \begin{tabular}{|l|} 
Authors \\
\end{tabular} & Date \\
\hline $\begin{array}{l}\text { No. 701: The Effects of Multiple Minimum Wages Throughout the } \\
\text { Labor Market }\end{array}$ & $\begin{array}{l}\text { T. H. Gindling and Katherine } \\
\text { Terrell }\end{array}$ & May 2004 \\
\hline No. 700: Minimum Wages, Inequality and Globalization & $\begin{array}{l}\text { T. H. Gindling and Katherine } \\
\text { Terrell }\end{array}$ & May 2004 \\
\hline No. 699: Self-Selection and Earnings During Volatile Transition & Ralitza Dimova and Ira Gang & May 2004 \\
\hline No. 698: Ecology and Violence: The Environmental Dimensions of War & $\begin{array}{l}\text { Timothy L. Fort and Cindy A. } \\
\text { Schipani }\end{array}$ & May 2004 \\
\hline $\begin{array}{l}\text { No. 697: Russian Cities in Transition: The Impact of Market Forces in } \\
\text { the 1990s }\end{array}$ & Ira N. Gang and Robert C. Stuart & May 2004 \\
\hline $\begin{array}{l}\text { No. 696: Firm Ownership and Internal Labor Practices in a Transition } \\
\text { Economy: An Exploration of Worker Skill Acquisition in Vietnam }\end{array}$ & Jed Friedman & May 2004 \\
\hline No. 695: The Unanticipated Effects of Insider Trading Regulation & $\begin{array}{l}\text { Art A. Durnev and Amrita S. } \\
\text { Nain }\end{array}$ & May 2004 \\
\hline $\begin{array}{l}\text { No. 694: Volatile Interest Rates, Volatile Crime Rates: A New } \\
\text { Argument for Interest Rate Smoothing }\end{array}$ & Garett Jones and Ali M. Kutan & May 2004 \\
\hline $\begin{array}{l}\text { No. } 693 \text { Money Market Liquidity under Currency Board - Empirical } \\
\text { Investigations for Bulgaria }\end{array}$ & $\begin{array}{l}\text { Petar Chobanov and Nikolay } \\
\text { Nenovsky }\end{array}$ & May 2004 \\
\hline $\begin{array}{l}\text { No. 692: Credibility and Adjustment: Gold Standards Versus Currency } \\
\text { Boards }\end{array}$ & $\begin{array}{l}\text { Jean Baptiste Desquilbet and } \\
\text { Nikolay Nenovsky }\end{array}$ & May 2004 \\
\hline $\begin{array}{l}\text { No. 691: Impact of Cross-listing on Local Stock Returns: Case of } \\
\text { Russian ADRs }\end{array}$ & Elena Smirnova & May 2004 \\
\hline $\begin{array}{l}\text { No. 690: Executive Compensation, Firm Performance, and State } \\
\text { Ownership in China:Evidence from New Panel Data }\end{array}$ & Takao Kato and Cheryl Long & May 2004 \\
\hline $\begin{array}{l}\text { No. 689: Diverging Paths: Transition in the Presence of the Informal } \\
\text { Sector }\end{array}$ & Maxin & May 2004 \\
\hline $\begin{array}{l}\text { No. 688: What Causes Bank Asset Substitution in Kazakhstan? } \\
\text { Explaining Currency Substitution in a Transition Economy }\end{array}$ & Sharon Eicher & May 2004 \\
\hline $\begin{array}{l}\text { No. 687: Financial Sector Returns and Creditor Moral Hazard: Evidence } \\
\text { from Indonesia, Korea and Thailand }\end{array}$ & $\begin{array}{l}\text { Ayse Y. Evrensel and Ali M. } \\
\text { Kutan }\end{array}$ & May 2004 \\
\hline $\begin{array}{l}\text { No. 686: Instability in Exchange Rates of the World Leading } \\
\text { Currencies: Implications of a Spatial Competition Model }\end{array}$ & $\begin{array}{l}\text { Dirk Engelmann, Jan Hanousek } \\
\text { and Evzen Kocenda }\end{array}$ & May 2004 \\
\hline $\begin{array}{l}\text { No. 685: Corporate Spinoffs, Privatization, and Performance in } \\
\text { Emerging Markets }\end{array}$ & $\begin{array}{l}\text { Jan Svejnar, Evzen Kocenda and } \\
\text { Jan Hanousekf }\end{array}$ & May 2004 \\
\hline $\begin{array}{l}\text { No. 684: CPI Bias and Real Living Standards in Russia During the } \\
\text { Transition }\end{array}$ & $\begin{array}{l}\text { John Gibson, Steven Stillman and } \\
\text { Trinh Le }\end{array}$ & May 2004 \\
\hline $\begin{array}{l}\text { No. 683: Mission Implausible III: Measuring the Informal Sector in a } \\
\text { Transition Economy using Macro Methods }\end{array}$ & Jan Hanousek and Filip Palda & May 2004 \\
\hline $\begin{array}{l}\text { No. 682: The Other Side of the Moon: The Data Problem in Analyzing } \\
\text { Growth Determinants }\end{array}$ & $\begin{array}{l}\text { Jan Hanousek, Dana Hajkova and } \\
\text { Randall K. Filer }\end{array}$ & May 2004 \\
\hline $\begin{array}{l}\text { No. 681: Consumers' Opinion of Inflation Bias Due to Quality } \\
\text { Improvements }\end{array}$ & $\begin{array}{l}\text { Jan Hanousek and Randall K. } \\
\text { Filer }\end{array}$ & May 2004 \\
\hline $\begin{array}{l}\text { No. 680: IMF-Related Announcements, Fundamentals, and Creditor } \\
\text { Moral Hazard: A Case Study of Indonesia }\end{array}$ & $\begin{array}{l}\text { Ayşe Y. Evrensel and Ali M. } \\
\text { Kutan }\end{array}$ & May 2004 \\
\hline No. 679: Privatization Matters: Bank Efficiency in Transition Countries & $\begin{array}{l}\text { John P. Bonin, Iftekhar Hasan and } \\
\text { Paul Wachtel }\end{array}$ & Apr. 2004 \\
\hline $\begin{array}{l}\text { No. 678: Does Market Liberalisation Reduce Gender Discrimination? } \\
\text { Econometric Evidence from Hungary, 1986-1998 }\end{array}$ & $\begin{array}{l}\text { Dean Jolliffe and Nauro F. } \\
\text { Campos }\end{array}$ & Apr. 2004 \\
\hline $\begin{array}{l}\text { No. 677: Governance and Performance of Microfinance Institutions in } \\
\text { Central And Eastern Europe and the Newly Independent States }\end{array}$ & Valentina Hartarska & Apr. 2004 \\
\hline $\begin{array}{l}\text { No. 676: Equilibrium Exchange Rates in the Transition: The Tradable } \\
\text { Price-Based Real Appreciation and Estimation Uncertainty }\end{array}$ & $\begin{array}{l}\text { Balázs Égert and Kirsten } \\
\text { Lommatzsch }\end{array}$ & Apr. 2004 \\
\hline
\end{tabular}

